\title{
Assessment of heavy metals in RDF for thermochemical conversion
}

\author{
Ismail Babatunde Adefeso ${ }^{1 *}$, Daniel Ikhu-Omoregbe ${ }^{2}$ and Yusuf M. Isa ${ }^{1}$ \\ ${ }^{1}$ Department of Chemical Engineering, Cape Peninsula University Technology, Cape Town Campus, Cape Town 8000, South Africa \\ ${ }^{2}$ Department of Chemical Engineering, Durban University Technology, Steve Biko Campus, Durban, 4001, South Africa
}

\begin{abstract}
Thermal treatment applications towards production of energy from raw and pre-treated municipal solid waste (MSW) are continuously growing context in contemporary waste-to-energy technology. The quality of MSW needs an improved analysis to enhance her choice of energy exploitation and environmental assessment of fly and bottom ashes associated with thermochemical conversions. The MSW were collected from municipal solid waste disposal facilities (MSWDF) in Cape Town to investigate heavy metals distributions in MSW. The MSW were pre-treated to improve the quality of MSW. The 7700 Series quadrupole ICP-MS solution method was used to determine concentrations and distributions of some heavy metals from MSWDF in Cape Town. This study further predicted distributions of heavy metals in fly and bottom ashes by a model. The results showed that accumulation of high concentrations of heavy metals in bottom ash residue could be a good remedy for heavy metals control. The heavy metals (especially $\mathrm{Pb}, \mathrm{Zn}$ and $\mathrm{Hg}$ ) emissions could be technically monitored and controlled from escaping to urban air-sheds atmosphere and prevent from their consequential secondary environmental and health implication.
\end{abstract}

\section{Introduction}

The contemporary solid waste management systems include waste collections and segregating followed by one or more of the following options: recovery of secondary materials by recycling of solid wastes, biological treatment of organic waste, production of marketable composts, and thermal treatments by various forms thermochemical conversions to recover energy in the form of heat and electricity and landfilling [1-8]. The application of the solid waste management systems in developing and under-developed countries are not fully employed to tackle the challenges of municipal solid wastes (MSW).The rate of production of MSW in developing countries demands paramount attention to tackle ever growing challenge of untreated amount of MSW in most developing and under-developed nations [9-11]. This is because the impacts are becoming serious in terms of lingering environmental challenges on (air, land, surface and subsurface water flow) as well as short and long-time health implications [1, 10, 12-14]. The classification of solid waste in some African countries are not conclusive because more than 48 million tonnes of solid wastes are still left unclassified. The order of $10 \%$ of all solid wastes generated in South Africa was recycled in 2011. Landfilling of MSW releases GHGs and volatile organic compounds along with leachable toxic heavy metals to the surrounding environment [15-17]. The enormous emission of GHGs from some existing and closed landfilling site in South Africa is calling for thorough and serious solution [18, 19]. Okonkwo and Mothiba [20] found a high concentration of lead in the Madanzhe and Mvudi Rivers in Thohoyandou, South Africa, which was attributed to the effluent from a nearby sewage treatment plant and a waste dumping site.
These heavy metals contaminants pose severe health implication when released and find the way into the ecosystem. Similar experiences were observed by the following authors suggesting actions that might lead to the uncontrolled release of heavy metals into ecosystem through disposal of untreated incineration ashes and MSW [17, 19, 21-27]. Mangizvo [28] identified in a study of the Mucheke MSW dumpsite in Masvingo, Zimbabwe, that soil within a $50 \mathrm{~m}$ radius had been contaminated by trace metals of lead, iron, copper, zinc, and phosphorus. These heavy metals migration and temporal distribution concentrations of heavy metals contaminants [29-31] deserve further study to reduce the infiltration into the ecosystem. Moreover, incineration of MSW to generate energy is one of the traditional methods of dealing with combustible waste efficiently because it reduces the volume and mass of MSW. Although heavy metals are inert and give off no energy when they are incinerated, the high temperatures of a MSW furnace cause metals to partially volatize, resulting in release of toxic poisonous fumes and fly ash [29-32]. In addition, it has drawbacks as well particularly hazardous emissions $\left(\mathrm{NO}_{\mathrm{x}}, \mathrm{SO}_{\mathrm{x}}, \mathrm{HCl}\right.$ and harmful organic compounds) [14, 33-35] and harmful process residues [36]. Incineration of MSW generates fly and bottom ashes which release leachable toxic heavy metals, dioxin, furans and volatile organic compounds [24, $25,29,37]$. The thermal treatments may be very promising remedy for control dangerous emission of furan, dioxin and other harmful emissions but choice of the thermochemical conversion is very important. The results data of heavy metals concentrations in pre-treated MSW were presented and discussed also determination of spatial distribution of heavy metals in bottom ash residues was obtained via model used by the studies of Belevi and Moench [38] and Yao, Li, Kong, Wu, He and Shen [23]. The focus of this study was to quantify the distribution of

\footnotetext{
* Corresponding author: Ismaila@dut.ca.za
} 
these heavy metals (Al, As, Cd, Cr, Cu, Fe, Hg, Mn, Mo, $\mathrm{Ni}, \mathrm{Pb}$, and $\mathrm{Zn}$ ) present in various MSWDF in Cape Town.

\section{Methodology}

\subsection{ICP-MS solutions method}

The MSW samples were collected from solid waste disposal facilities (SWDF) around the settlements in Cape Town. They are Kraaifontein, Athlone, Woodstock, Tygerdal, Belhar, Killarney, Wynberg, Macassar, Delft, Welengen, Ladies Mile, Retreat and Coastal Park (KF, ARTS, WS, TG, BL, KL, WY, MC, DF, WG, LM, RT, and $\mathrm{CP}$ ). The MSW were pre-treated, shredded again, milled and sieved at a specific mesh $(2-5 \mathrm{~mm})$ this was to ensure that MSW was properly homogenized. The pretreated MSW samples $(0.25-0.40 \mathrm{~g})$ were first digested with USEPA standard procedure for digestion was used. The procedures normally use acid and heat to break organo-metallic bonds and free ions for analysis. The ICPMS solution method was used to determine heavy metals (Al, Fe, $\mathrm{Zn}, \mathrm{Cu}, \mathrm{Cr}, \mathrm{Mn}, \mathrm{Co}$ and $\mathrm{Hg}$ ) concentration in MSW. The 7700 Series quadrupole ICP-MS from Agilent Technologies provides an unmatched combination of high performance and simplicity of operation, redefining the benchmark for ICP-MS.

\section{Results and discussion}

The heavy metals concentrations in pre-treated MSW measurement were considered in order to evaluate modelled environmental implications during and after thermochemical conversion. This was necessary to prepare for mitigation procedures to corrosion and emissions that maybe exposed to environment after disposal residues containing heavy metals (except $\mathrm{Hg}$ and Cd) within the thermochemical conversion process, its residues and disposals. In this study, the main composition of MSW was categorized to combustible and noncombustible substances. Heavy metals found in MSW have fundamental implications on production of fly and bottom ash and their disposals. They might be responsible for fouling effects, corrosion and pollutant emissions during thermochemical reactions [39].

\subsection{Heavy metals and environment}

The heavy metals are found naturally in the environment and are released from a range of anthropogenic activities such as combustion processes. Though some studies had been conducted, there is need to know more on heavy metals distributions in pre-treated MSW relating to thermochemical conversions $[1,8,31,36,40-44]$.
Environmental impacts of heavy metals behaviour during thermochemical conversion were also discussed.

Nonetheless, there is dearth of studies on availability and spatial distribution of heavy metals in Cape Town MSW.

\subsection{Quantification of heavy metals in pre-treated MSW}

The overall concentrations of the heavy metals in pretreated MSW obtained from the MSWDF in Cape Town were summarily presented in table 1 and figure 1 . Al and Fe concentrations data from MSW were the highest for obvious reason and similar to the range usually obtained in most soil samples. Both concentrations showed a wide range of high concentration which was very significant for MSW. These concentrations may not be seriously affect thermochemical implication but contribution to base line earth natural concentrations which might be point of concern (figure 1). The $\mathrm{Cd}$ concentration was noticed to have had widest range of concentration but there was odd relations with one facility have extremely high concentration of $\mathrm{Cd}$ compared to others. The average concentrations of heavy metals were pre-treated MSW samples were in the following order of concentrations; $\mathrm{Al}>$ $\mathrm{Fe}>\mathrm{Cr}>\mathrm{Zn}>\mathrm{Mn}>\mathrm{Ba}>\mathrm{Ni}>\mathrm{Cu}>\mathrm{Pb}>\mathrm{Co}>\mathrm{V}>\mathrm{As}>$ $\mathrm{Mo}>\mathrm{Sb}>\mathrm{Cd}>\mathrm{Se}>\mathrm{Hg}$ unlike the study of Haiying, Youcai and Jingyu [24] which reported this order of heavy metals from MSW incineration Plant showed that content of heavy metals follows the sequence of $\mathrm{Zn}>\mathrm{Pb}>\mathrm{Cu}>$ $\mathrm{Cr}>\mathrm{As}>\mathrm{Ni}>\mathrm{Cd}$. Highest concentrations of heavy metals were observed in $\mathrm{Al}, \mathrm{Fe}, \mathrm{Zn}$ and $\mathrm{Cr}$ were 13508.10 $\mathrm{mg} / \mathrm{Kg}$ (CP), $10230.40 \mathrm{mg} / \mathrm{Kg}$ (KF), $316.14 \mathrm{mg} / \mathrm{Kg}$ (TG), and $312.60 \mathrm{mg} / \mathrm{Kg}(\mathrm{KF})$ respectively. These heavy metal quantifications were shown in table 1 while other remaining quantifications of heavy metals were also presented in figures 1 - 6 respectively. Relatively high standard deviation was observed among all the heavy metals content of pre-treated MSW except for Sb while Al and $\mathrm{Fe}$ (figure 2) were unusually high compare to other heavy metals as earlier observed for apparent reason. This might be due to heterogeneous distribution of the heavy metals in all the sampling locations.

The heavy metal concentrations from pre-treated MSW were compared with that of soils. The concentrations of heavy metals obtained were quite below the recommended for residential, industrial and commercial locations in china [23]. The results indicated that the average values of all the heavy metals from all the pre-treated MSW were within the standard limits [45]. However, useful application through possible recovery of these heavy metals may be considered depending on the concentration of heavy metals in MSW among other factors. 
Table 1. Concentrations distribution of heavy metals in pre-treated MSW in Cape Town

\begin{tabular}{cccc}
\hline $\begin{array}{c}\text { Heavy } \\
\text { Metals }\end{array}$ & $\begin{array}{c}\text { Concentrations } \\
\text { Range }(\mathbf{m g} / \mathbf{K g})\end{array}$ & $\begin{array}{c}\text { Mean } \\
\text { Concentrations } \\
(\mathbf{m g} / \mathbf{K g})\end{array}$ & $\begin{array}{c}\text { Standard } \\
\text { Deviation }\end{array}$ \\
\hline $\mathbf{F e}$ & $788.01-10230.40$ & 4978.294 & 2731.064 \\
$\mathbf{A l}$ & $593.44-13508.10$ & 5220.651 & 3403.408 \\
$\mathbf{Z n}$ & $67.76-316.10$ & 156.154 & 62.249 \\
$\mathbf{C r}$ & $66.44-312.60$ & 171.694 & 69.576 \\
$\mathbf{M n}$ & $57.96-199.10$ & 109.169 & 38.603 \\
$\mathbf{N i}$ & $27.03-122.50$ & 72.727 & 27.406 \\
$\mathbf{C u}$ & $15.81-134.40$ & 50.563 & 33.588 \\
$\mathbf{C o}$ & $6.12-100.00$ & 26.743 & 21.764 \\
$\mathbf{A s}$ & $2.23-103.50$ & 12.616 & 25.490 \\
$\mathbf{S b}$ & $0.18-3.00$ & 1.390 & 0.799 \\
$\mathbf{C d}$ & $0.13-96.30$ & 7.720 & 24.779 \\
$\mathbf{H g}$ & $0.04-105.30$ & 7.173 & 27.151 \\
$\mathbf{P b}$ & $9.41-97.50$ & 35.256 & 26.811 \\
\hline
\end{tabular}

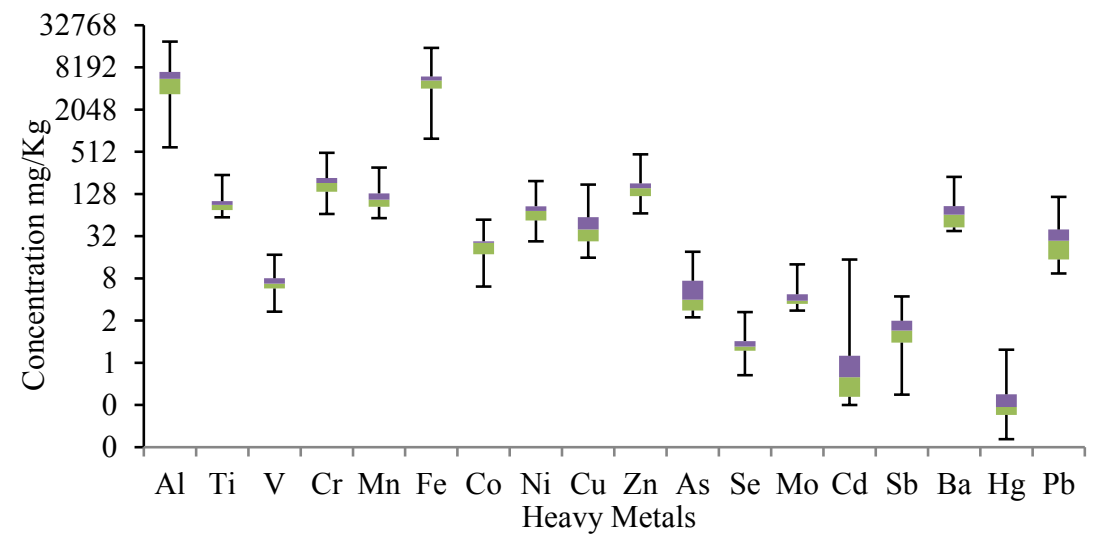

Figure. 1. Log plot distributions of heavy metals concentrations in pre-treated MSW from SWDF in Cape Town

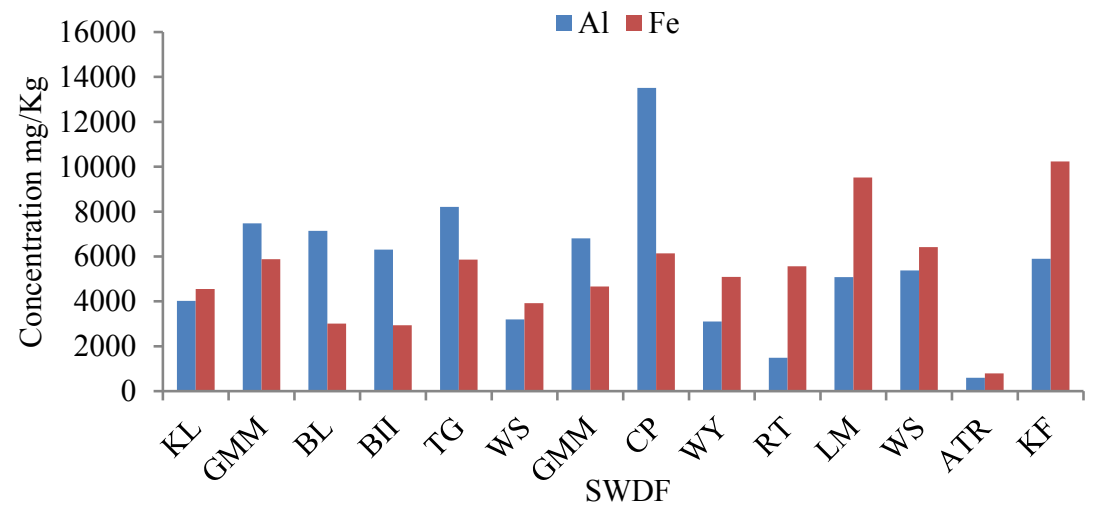

Figure. 2. Al and Fe concentrations in pre-treated MSW from SWDF in Cape Town. 


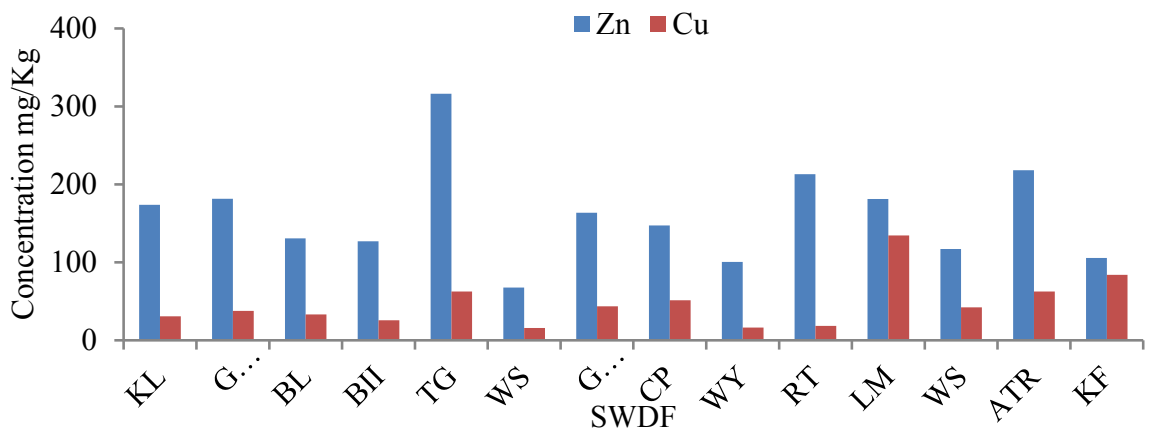

Figure. 3. $\mathrm{Zn}$ and $\mathrm{Cu}$ concentrations in pre-treated MSW from SWDF in Cape Town.

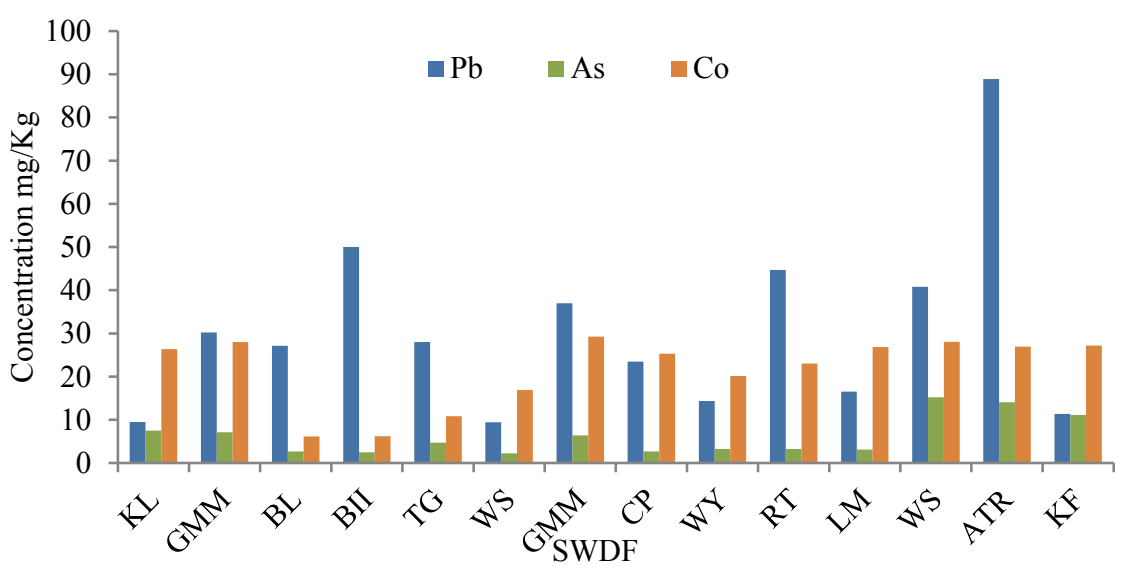

Figure. 4. $\mathrm{Pb}$, As and Co concentrations in pre-treated MSW from SWDF in Cape Town.

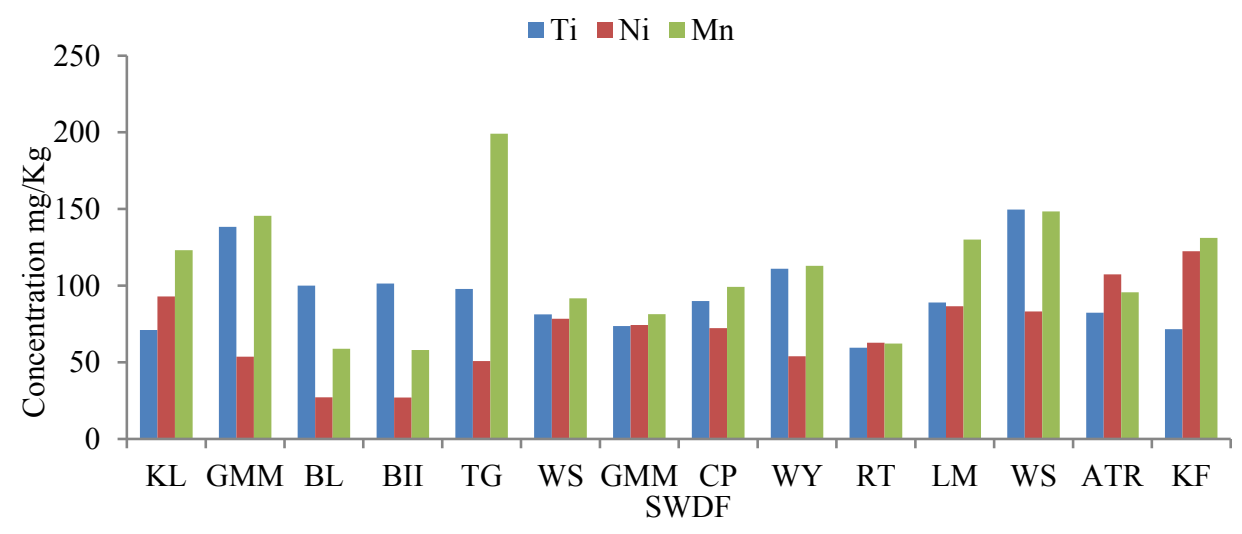

Figure. 5. Ti, Ni, and Mn, concentrations in pre-treated MSW from SWDF in Cape Town.

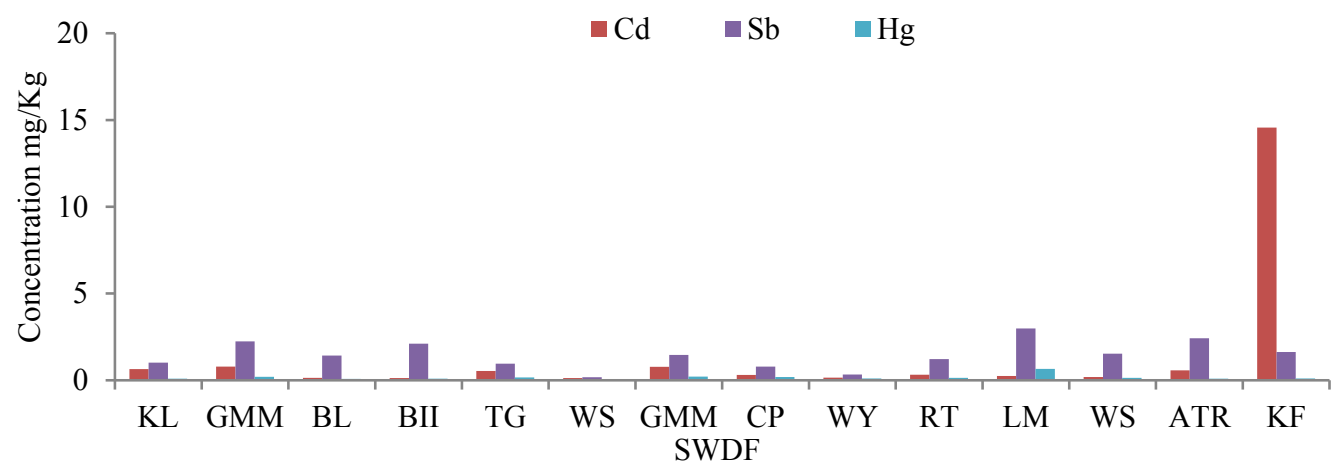

Figure. 6. $\mathrm{Cd}, \mathrm{Sb}$, and $\mathrm{Hg}$ concentrations in pre-treated MSW from SWDF in Cape Town. 


\subsection{Quantification of heavy metals in bottom ash}

Apart from likely catalytic contribution of some compounds of heavy metals (Alkali metals, Al, Ti) available in pre-treated MSW, most heavy metals will be concentrated in both fly and bottom ashes. Studies had reported larger fractions of heavy metals fractions concentrated in bottom ashes and most of these heavy metals may be recovered [23, 26, 38, 41, 46-49]. Generally bottom ashes contain $\mathrm{SiO}_{2}, \mathrm{CaO}, \mathrm{Al}_{2} \mathrm{O}_{3}, \mathrm{Fe}_{2} \mathrm{O}_{3}$ $\mathrm{Na}_{2} \mathrm{O}, \mathrm{K}_{2} \mathrm{O}$ and $\mathrm{MgO}$ [46-48]. The study of Yao, Li, Kong, $\mathrm{Wu}, \mathrm{He}$ and Shen [23] on distribution of heavy metals between fly and bottom ashes using transfer coefficient and they concluded that the average range of transfer coefficient for $\mathrm{Cu}, \mathrm{Cr}, \mathrm{Mn}, \mathrm{Ni}, \mathrm{Cd}, \mathrm{Co}, \mathrm{As}, \mathrm{Mo}, \mathrm{Pb}$, and $\mathrm{Zn}$ range between 0.533 and 0.947 for As and $\mathrm{Mn}$ respectively. Also the study of Belevi and Moench [38] investigated group of eighteen heavy metals and nonmetals show a range of $0.120-0.989$ for heavy metals and for non-metals. However the transfer coefficient of $\mathrm{Hg}$ for both studies are significantly low or negligible (almost not detected). This showed $\mathrm{Hg}$ had been completely transferred to fly ashes. The following studies [23, 26, 4652] used incineration towards waste-to-energy technology with untreated MSW. Most of the studies recommended pre-treatment in the form of source re-classification of MSW [53] to enhance the quality of bottom ash residue for effective heavy metals recovery.

Yao, Li, Kong, Wu, He and Shen [23] reported some studies on heavy metals concentration distribution in MSW thermochemical conversion plant were mostly concentrated into the bottom ash residues during the incineration process. The reports indicated heavy metals like $\mathrm{As}, \mathrm{Fe}, \mathrm{Cu}, \mathrm{Cr}, \mathrm{Pb}, \mathrm{Co}, \mathrm{Ni}$ and $\mathrm{Zn}$ were highly concentrated mainly in the bottom ash residues with up to an average of $80 \%$. However, special attention was paid to these metals $\mathrm{Cd}, \mathrm{As}, \mathrm{Cu}, \mathrm{Cr}, \mathrm{Pb}$ and $\mathrm{Zn}$ because of proven high toxicity to the environment. This relation below was used to quantify possible heavy metals that will Table 2. Calculated heavy metals concentrations in bottom ashe residue

\begin{tabular}{ccc}
\hline $\begin{array}{c}\text { Heavy } \\
\text { Metals }\end{array}$ & $\begin{array}{c}\text { HMCBAIJ } \\
\text { Min }(\mathbf{m g} / \mathbf{K g})\end{array}$ & $\begin{array}{c}\text { HMCBAIJ } \\
\text { Max }(\mathbf{m g} / \mathbf{K g})\end{array}$ \\
\hline $\mathbf{A l}$ & 1890.106 & 43023.29 \\
$\mathbf{C r}$ & 218.5813 & 1028.547 \\
$\mathbf{F e}$ & 2727.698 & 35412.6 \\
$\mathbf{C o}$ & 18.85146 & 307.9555 \\
$\mathbf{N i}$ & 90.82455 & 411.6455 \\
$\mathbf{C u}$ & 53.11093 & 451.5965 \\
$\mathbf{Z n}$ & 101.9803 & 475.789 \\
$\mathbf{A s}$ & 5.922989 & 275.2099 \\
$\mathbf{M o}$ & 8.370719 & 301.7468 \\
$\mathbf{C d}$ & 0.043768 & 33.70738 \\
$\mathbf{H g}$ & 0.002848 & 7.372194 \\
$\mathbf{P b}$ & 14.48866 & 150.0975 \\
\hline
\end{tabular}

be transferred to bottom ash residue during and after thermochemical conversions [23, 38].

$$
K_{i j}=\frac{C_{B A i j} * R_{j}}{C_{w i j} *\left(1-y_{j}\right)}
$$

Where $\mathrm{K}_{i, j}$ was the transfer coefficient of the heavy metal $i$ from the input MSW to the bottom ash of location $j . \mathrm{C}_{B A i, j}$ was the content of the heavy metal $i$ in the bottom ash of city location $j\left(\mathrm{mg} / \mathrm{kg}\right.$ dry weight). $\mathrm{C}_{W i, j}$ was the content of heavy metal $i$ in the input MSW of location $j$ (mg/kg dry weight). $\mathrm{R}_{j}$ was the bottom ash mass production ratio of the incinerator in location $j$, which was about $0.2-0.3$. $\mathrm{y}_{j}$ was the water ratio of the input MSW of the incinerator in location $j$. The results data obtained for quantification of heavy metals in bottom ash residue through that model equation related above were presented in table 2. Using coefficient of transferred from the studies of Belevi and Moench [38] and Yao, Li, Kong, Wu, He and Shen [23] the quantity of heavy metals obtained had substantial decreased and transferred to bottom ash (tables 2 - 3). Litophilic characteristic made some heavy metals $(\mathrm{Al}, \mathrm{Cr}, \mathrm{Cu}$, and $\mathrm{Fe}$ ) to remain in bottom ash. All the heavy metals have significant presence in bottom ash except $\mathrm{Sb}$ and $\mathrm{Hg}$. This is similar to previous studies mentioned early in the discussion. The result data presented in table 2 is substantially lower than that of Yao, Li, Kong, Wu, He and Shen [23] and [31], Jung, Matsuto, Tanaka and Okada [54] for set of heavy metals except for Co, Mo and $\mathrm{Ni}$ while the study of Hu et la. [55] presented lower value for $\mathrm{Cu}$ and $\mathrm{Cd}, \mathrm{Pb}$ and $\mathrm{Zn}$ were higher. The distribution of heavy metals during thermochemical conversion have significant variance depending on the choice of reactions mechanisms [30, 32, 43, 44]. Heterogeneity of the raw MSW was expected to be main factor for this wide difference in concentrations. The heterogeneous characteristics were reflected with high concentration of some heavy metals such as $\mathrm{Cr}, \mathrm{Cu}, \mathrm{Mn}$ and $\mathrm{Zn}$.

Table 3. Heavy metals concentrations in bottom ash from literature [54]

\begin{tabular}{ccc}
\hline $\begin{array}{c}\text { Heavy } \\
\text { Metals }\end{array}$ & $\begin{array}{c}\text { HMCBAIJ Min } \\
(\mathbf{m g} / \mathbf{K g})\end{array}$ & $\begin{array}{c}\text { HMCBAIJ Max } \\
(\mathbf{m g} / \mathbf{K g})\end{array}$ \\
\hline $\mathbf{A l}$ & $10600-43420$ & $147000-68060$ \\
$\mathbf{C r}$ & $6.6-60$ & $2260-256$ \\
$\mathbf{F e}$ & $500-22000$ & $200000-86800$ \\
$\mathbf{C u}$ & $77-414$ & $13200-3720$ \\
$\mathbf{Z n}$ & $500-1280$ & $33000-4800$ \\
$\mathbf{A s}$ & $0-0.1$ & $93-3.5$ \\
$\mathbf{C d}$ & $0.04-0.8$ & $91-14$ \\
$\mathbf{S b}$ & $5-37$ & $306-192$ \\
$\mathbf{H g}$ & 0.001 & 5.5 \\
$\mathbf{P b}$ & $8-140$ & $10900-1320$ \\
\hline
\end{tabular}


High transfer coefficients indicate the heavy metals are mainly transferred to the bottom ash. Though $\mathrm{Hg}$ has potential environmental health risk but the amount is expected to be below required standard for emissions. Also, some bottom ashes heavy metals $(\mathrm{Cd}, \mathrm{Cu}, \mathrm{Pb}$, and $\mathrm{Zn}$ ) are regarded as relatively unstable, thus it will be very crucial to conduct further studies for recovery and reuse of the heavy metals to avoid contamination of immediate ecosystem and bio-toxicity.

\section{Conclusions}

The accumulation of high concentrations of heavy metals in bottom ash residue from thermochemical conversion could be a good remedy for heavy metals control. The heavy metals ( $\mathrm{Pb}, \mathrm{Zn}$ and $\mathrm{Hg}$ ) emissions were

\section{References}

1. H. Tian et al., Atmospheric pollution problems and control proposals associated with solid waste management in China: A review. Journal of Hazardous Materials 252-253, 142-154 (2013)

2. F. Yan et al., Hydrogen-rich gas production by steam gasification of char derived from cyanobacterial blooms $(\mathrm{CDCB})$ in a fixed-bed reactor: Influence of particle size and residence time on gas yield and syngas composition. International Journal of Hydrogen Energy 35, 10212-10217 (2010)

3. Y. Hui, W. Li'ao, S. Fenwei, H. Gang, Urban solid waste management in Chongqing: Challenges and opportunities. Waste Management 26, 1052-1062 (2006)

4. H. Wang et al., Study of the application and methods for the comprehensive treatment of municipal solid waste in northeastern China. Renewable and Sustainable Energy Reviews 52, 1881-1889 (2015)

5. J. T. S. Pedersen, H. Manhice, The hidden dynamics of household waste separation: An anthropological analysis of user commitment, barriers, and the gaps between a waste system and its users. Journal of Cleaner Production 242, 116285 (2020)

6. O. K. M. Ouda et al., Waste to energy potential: A case study of Saudi Arabia. Renewable and Sustainable Energy Reviews 61, 328-340 (2016)

7. M. Rizwan, Y. Saif, A. Almansoori, A. Elkamel, Environmental Performance of Municipal Solid Waste Processing Pathways. Energy Procedia 158, 3363-3368 (2019)

8. L. Lombardi, E. Carnevale, A. Corti, A review of technologies and performances of thermal treatment systems for energy recovery from waste. Waste Management 37, 26-44 (2015)

9. I.-H. Hwang, J. Kobayashi, K. Kawamoto, Characterization of products obtained from pyrolysis and steam gasification of wood waste, RDF, and RPF. Waste Management 34, 402-410 (2014) technically monitored and controlled from escaping to urban air-sheds atmosphere and prevent from their consequential secondary environmental and health implication. The thermochemical technology hence offers heavy metals emission mitigation to uncontrolled emission from open-air incinerations and the likes. This study pre-treated all the samples of MSW used for its heavy metals quantification before and after thermochemical conversion and it was shown in the concentrations of the heavy metals found in all the samples falling behind all those obtained in incinerator without sorting or pre-treatment of MSW. However, before disposal or reuse of bottom ash residue, the residue will require further evaluation study for potential environmental impacts. This will be helpful for crucial considerations for policy and decision maker on heavy metals mobility in MSW thermochemical conversion technology from cradle-to-grave in Cape Town.

10. Y. Pujara, P. Pathak, A. Sharma, J. Govani, Review on Indian Municipal Solid Waste Management practices for reduction of environmental impacts to achieve sustainable development goals. Journal of Environmental Management 248, 109238 (2019)

11. Y. Aryan, P. Yadav, S. R. Samadder, Life Cycle Assessment of the existing and proposed plastic waste management options in India: A case study. Journal of Cleaner Production 211, 1268-1283 (2019)

12. S. N. Othman, Z. Zainon Noor, A. H. Abba, R. O. Yusuf, M. A. Abu Hassan, Review on life cycle assessment of integrated solid waste management in some Asian countries. Journal of Cleaner Production 41, 251-262 (2013)

13. E. Kirtay, Recent advances in production of hydrogen from biomass. Energy Conversion and Management 52, 1778-1789 (2011)

14. Y. Yu et al., Effects of ambient air pollution from municipal solid waste landfill on children's nonspecific immunity and respiratory health. Environmental Pollution 236, 382-390 (2018)

15. I. Sibiya et al., Targeted and non-target screening of persistent organic pollutants and organophosphorus flame retardants in leachate and sediment from landfill sites in Gauteng Province, South Africa. Science of The Total Environment 653, 1231-1239 (2019)

16. S. S. W. Mavimbela, O. O. Ololade, J. J. van Tol, M. P. Aghoghovwia, Characterizing landfill leachate migration potential of a semi-arid duplex soil. Heliyon 5, e02603 (2019)

17. E. Vetrimurugan et al., Comprehensive study on metal contents and their ecological risks in beach sediments of KwaZulu-Natal province, South Africa. Marine Pollution Bulletin 149, 110555 (2019)

18. C. Vossberg, K. Mason-Jones, B. Cohen, An energetic life cycle assessment of C\&amp;D waste and container glass recycling in Cape Town, South 
Africa. Resources, Conservation and Recycling 88, 39-49 (2014)

19. E. Friedrich, C. Trois, Current and future greenhouse gas (GHG) emissions from the management of municipal solid waste in the eThekwini Municipality - South Africa. Journal of Cleaner Production 112, 4071-4083 (2016)

20. J. O. Okonkwo, M. Mothiba, Physico-chemical characteristics and pollution levels of heavy metals in the rivers in Thohoyandou, South Africa. Journal of Hydrology 308, 122-127 (2005)

21. T.-H. Kwak et al., Environmental aspects of gasification of Korean municipal solid waste in a pilot plant. Fuel 85, 2012-2017 (2006)

22. C. Xiaoli, T. Shimaoka, C. Xianyan, G. Qiang, Z. Youcai, Characteristics and mobility of heavy metals in an MSW landfill: Implications in risk assessment and reclamation. Journal of Hazardous Materials 144, 485-491 (2007)

23. J. Yao et al., Content, mobility and transfer behavior of heavy metals in MSWI bottom ash in Zhejiang province, China. Fuel 89, 616-622 (2010)

24. Z. Haiying, Z. Youcai, Q. Jingyu, Characterization of heavy metals in fly ash from municipal solid waste incinerators in Shanghai. Process Safety and Environmental Protection 88, 114-124 (2010)

25. Y. Zhao, W. Xing, W. Lu, X. Zhang, T. H. Christensen, Environmental impact assessment of the incineration of municipal solid waste with auxiliary coal in China. Waste Management 32, 1989-1998 (2012)

26. T. Sekito, Y. Dote, K. Onoue, H. Sakanakura, K. Nakamura, Characteristics of element distributions in an MSW ash melting treatment system. Waste Management 34, 1637-1643 (2014)

27. J. Edokpayi, J. Odiyo, O. Popoola, T. Msagati, Assessment of Trace Metals Contamination of Surface Water and Sediment: A Case Study of Mvudi River, South Africa. Sustainability 8, 135 (2016)

28. R. V. Mangizvo, Management practices at the Mucheke municipal solid waste disposal site in Masvingo City, in

Zimbabwe. Journal of Sustainable Development in Africa 10, 147-164 (2008)

29. J. Haberl, R. Koralewska, S. Schlumberger, M. Schuster, Quantification of main and trace metal components in the fly ash of waste-to-energy plants located in Germany and Switzerland: An overview and comparison of concentration fluctuations within and between several plants with particular focus on valuable metals. Waste Management 75, 361-371 (2018)

30. L. Chen, Y. Liao, X. Ma, Heavy metals volatilization characteristics and risk evaluation of co-combusted municipal solid wastes and sewage sludge without and with calcium-based sorbents. Ecotoxicology and Environmental Safety 182, 109370 (2019)
31. Y. Xiong et al., Distribution and characteristics of heavy metals in a first-generation monofill site for incinerator residue. Journal of Hazardous Materials 373, 763-772 (2019)

32. S. Abramov et al., Heavy metal mobility and valuable contents of processed municipal solid waste incineration residues from Southwestern Germany. Waste Management 79, 735-743 (2018)

33. G. McKay, Dioxin characterisation, formation and minimisation during municipal solid waste (MSW) incineration: review. Chemical Engineering Journal 86, 343-368 (2002)

34. A. Liu, F. Ren, W. Y. Lin, J.-Y. Wang, A review of municipal solid waste environmental standards with a focus on incinerator residues. International Journal of Sustainable Built Environment 4, 165-188 (2015)

35. K.-L. Hwang, S.-M. Choi, M.-K. Kim, J.-B. Heo, K.D. Zoh, Emission of greenhouse gases from waste incineration in Korea. Journal of Environmental Management 196, 710-718 (2017)

36. F. Hasselriis, A. Licata, Analysis of heavy metal emission data from municipal waste combustion. Journal of Hazardous Materials 47, 77-102 (1996)

37. M. J. Quina, J. C. Bordado, R. M. Quinta-Ferreira, Treatment and use of air pollution control residues from MSW incineration: An overview. Waste Management 28, 2097-2121 (2008)

38. H. Belevi, H. Moench, Factors Determining the Element Behavior in Municipal Solid Waste Incinerators. 1. Field Studies. Environmental Science \& Technology 34, 2501-2506 (2000)

39. B. M. Jenkins, L. L. Baxter, T. R. Miles Jr, T. R. Miles, Combustion properties of biomass. Fuel Processing Technology 54, 17-46 (1998)

40. H. Li, X. Qian, W. Hu, Y. Wang, H. Gao, Chemical speciation and human health risk of trace metals in urban street dusts from a metropolitan city, Nanjing, SE China. Science of The Total Environment 456-457, 212-221 (2013)

41. H. Long, X. Li, H. Wang, J. Jia, Biomass resources and their bioenergy potential estimation: A review. Renewable and Sustainable Energy Reviews 26, 344352 (2013)

42. B. Nowak, P. Aschenbrenner, F. Winter, Heavy metal removal from sewage sludge ash and municipal solid waste fly ash - A comparison. Fuel Processing Technology 105, 195-201 (2013)

43. Y. Xiong, F. Zhu, L. Zhao, H. Jiang, Z. Zhang, Heavy metal speciation in various types of fly ash from municipal solid waste incinerator. Journal of Material Cycles and Waste Management 16, 608-615 (2014)

44. F. Zhu et al., Heavy metal behavior in "WashingCalcination-Changing with Bottom Ash" system for recycling of four types of fly ashes. Waste Management 75, 215-225 (2018) 
45. USEPA, "Clean Water Act., Section Volume 58 " No. 32 (USEPA ( US Environmetal Protection Agency) 1993, 1993, 1993).

46. J. M. Chimenos, M. Segarra, M. A. Fernández, F. Espiell, Characterization of the bottom ash in municipal solid waste incinerator. Journal of Hazardous Materials 64, 211-222 (1999)

47. R. Forteza, M. Far, C. Seguí, V. Cerdá, Characterization of bottom ash in municipal solid waste incinerators for its use in road base. Waste Management 24, 899-909 (2004)

48. F.-Y. Chang, M.-Y. Wey, Comparison of the characteristics of bottom and fly ashes generated from various incineration processes. Journal of Hazardous Materials 138, 594-603 (2006)

49. E. Allegrini et al., Quantification of the resource recovery potential of municipal solid waste incineration bottom ashes. Waste Management 34, 1627-1636 (2014)

50. G.-J. Song, K.-H. Kim, Y.-C. Seo, S.-C. Kim, Characteristics of ashes from different locations at the MSW incinerator equipped with various air pollution control devices. Waste Management 24, 99-106 (2004)

51. Q. Song, Z. Wang, J. Li, Environmental performance of municipal solid waste strategies based on LCA method: a case study of Macau. Journal of Cleaner Production 57, 92-100 (2013)

52. A. Tozlu, E. Özahi, A. Abuşoğlu, Waste to energy technologies for municipal solid waste management in Gaziantep. Renewable and Sustainable Energy Reviews 54, 809-815 (2016)

53. A. A. Siddiqui, D. J. Richards, W. Powrie, Investigations into the landfill behaviour of pretreated wastes. Waste Management 32, 1420-1426 (2012)

54. C. H. Jung, T. Matsuto, N. Tanaka, T. Okada, Metal distribution in incineration residues of municipal solid waste (MSW) in Japan. Waste Management 24, 381-391 (2004)

55. J. Yu et al., Study on the behavior of heavy metals during thermal treatment of municipal solid waste (MSW) components. Environmental Science and Pollution Research 23, 253-265 (2016) 